\author{
Natalia Benkovska, \\ PhD (Candidate of Pedagogical Sciences), \\ associate professor of the Foreign Languages Department, \\ Odesa Institute of Trade and Economics of \\ Kyiv National University of Trade and Economics, \\ 6, Inglezi Str., Odessa, Ukraine
}

\title{
INTERDISCIPLINARY INTEGRATION OF PROFESSIONAL DISCIPLINES IN THE PROCESS OF TRAINING FUTURE SPECIALISTS OF SOCIONOMIC SPHERE
}

The professional education is implemented by integrated training courses providing the consistency in the study of subjects, helping to avoid duplication of the educational material, strengthening interdisciplinary connections and improving the educational process and introduction of new teaching technologies. Occupation-related knowledge is a basic "unit" of professional training. Its complexity is determined by the fact that professional knowledge is not homogeneous, it has the following three main components: general professional knowledge which distinguishes one profession from others, subject (disciplinary) knowledge which has the scientific and technological nature, and purely professional, differentiated knowledge. It has been proved that interdisciplinary integration of professional disciplines is a system of teachers' and students' work in the educational process that provides the unity of purposes, functions, content and structural elements of disciplines, promotes generalization, order and strength of professional knowledge and the formation of a cohesive professional outlook and harmonious developed personality of a future specialist. Organizational forms of interdisciplinary integration of professional disciplines are the following: interdisciplinary excursions, practical lessons, seminars, individual lessons, various types of internship, extracurricular activities, and interdisciplinary groups. It is not necessary to make adjustments in the content of professional disciplines which are taught for future specialists of socionomic sphere, the interdisciplinary integration can be achieved by optimizing the structure blocks of educational material, as well as by coordinating them for the purpose.

Keywords: interdisciplinary integration, integrated professional disciplines, interdisciplinary communication, professional knowledge.

\section{Introduction}

The current stage of the development of the national system of higher education is characterized by the lack of established legal framework that determines the establishment and the development of the system of continuous education; the formation of a free market of educational services in the sphere of additional professional education (private institutions, companies, private educational institutions) creating competitiveness and requiring the high quality of students' training; the globalization of educational space that creates a unity of professional issues; elaboration of cultural, conceptual, technological multiplicity of approaches to solving the problems of education, requiring professional and personal selfdetermination and social responsibility for one's own choice [3].

The higher education reformation involves training a graduate capable of mastering any specialty. In terms of higher professional education it is necessary to develop skills of conscious use of fundamental disciplines potential for dealing with professional tasks. It is possible only on the basis of interdisciplinary integration in terms of higher education [6:5].

The phenomenon of interdisciplinary communication was investigated by such researchers as I. Bochan, A. Bekrenev, A. Huriev, V. Kostiuk, T. Titovets and others. The review of scientific literature has made it possible to conclude that the issue of optimization of professional training of future specialists in the socionomic field by means of interdisciplinary communication between professional disciplines still remains understudied.

The implementation of courses of integrative educational and professional disciplines is discussed in the works of domestic and foreign scholars, such as V. Andrushchenko, I. Aleksashyna, G. Ball, V. Bevz, V. Bezrukova, M. Berulava, V. Bobrov, N. Voskresenska, K. Volynets, R. Gurevich, A. Danyluk, Yu. Dick, L. Kanischenko, B. Komissarov, O. Kulchytsky, S. Klepko, I. Kozlovska, Ya. Kmit, V. Ilchenko, E. Luzik, M. Makhmutov, V. Morgun, A. Pinsky, L. Tarasov, Yu. Tyunnykov, A. Usova, A. Hrypkova and others.

Thus, the paper aims to prove the importance of interdisciplinary integration in the process of training future specialists in the socionomic sphere.

According to the aim, the following tasks should be solved:

- to review scientific literature concerning the issue of realization of interdisciplinary communication in terms of modern educational space;

- to consider and suggest possible ways of using elements of interdisciplinary integration according to the requirements of educational institutions where future specialists of the socionomic field are trained; 
- to determine the levels of didactic integration according to the specificity of modern theory and methods of professional education.

\section{Discussion}

The Ukrainian researcher I. Bochan believes that "the main task of modern teachers is to implement innovative technologies, integral courses, to develop new interdisciplinary bonds" [8: 164], according to which "the establishment of interdisciplinary communication is an important component of the concept of interdisciplinary integration which involves the unification of knowledge, the synthesis of all forms of knowledge concerning every certain educational aim in a higher educational institution" [8: 18].

The differentiation of sciences causes the necessity of the opposite process, namely the integration of scientific knowledge. That is why one of the main contradictions of the modern educational system is the necessity of integration of a future specialist in professional training and opposed disciplines differentiation [1: 128].

The task of continuous education is to create real opportunities to influence the socio-cultural changes in order to create mobility, flexibility, adaptability and competitiveness. Education, in addition to assistance in adapting to the new conditions of variable environment, performs proactive function in preparing people for overcoming disorders of balance in social and professional spheres of life. Higher education is becoming a center of social regulation in the development of capacities of people who could assert their rights and freedoms in accordance with the changes taking place in the society. The strategy of education development in higher educational institutions of I-IV accreditation levels is considered in the context of the main aim of specialist's continuous education, namely, enriching his/her creative personal and professional potential throughout life. General civilizational context of continuous education in the graded university education is considered to be important as it provides individual adjustment of outlook, the development of a coherent, consistent personal concept of modern life and one's place in it.

We distinguish the following directions of professional training of students in higher educational institutions:

- identification of bonds between individual areas and the peculiarities of occupation (knowledge, abilities, skills);

- development of motives, interests, emotional and volitional sphere, professionally important qualities of a specialist in a particular kind of professional activities in the process of studying.

Taking the above mentioned directions as a basis we determine the following factors characterizing the peculiarities of the development of an individual as a professional in higher education: the formation of individual ways of solving professional tasks; the development of professional motives; the formation of proper correlation of the substantial professional motives (interest in the profession, the need for self-actualization) and adaptive ones (prestige, earnings).

The content of professional education is implemented by means of integrated training courses providing the consistency in studying subjects, helping to avoid educational material duplication, strengthening interdisciplinary connections and improving the educational process and implementing new teaching technologies.

According to legal resources, professional training provides students' acquisition of fundamental theoretical knowledge related to corresponding specialty and the development of practical skills and abilities required for professional activity. The content of professional training is determined by basic educational disciplines of a specialty; academic disciplines of professional focus. Professional training, based on the level system of higher education, is differentiated according to the respective educational levels acconting for the specifics of specialties.

Disciplines of specialty and disciplines of professional focus are taught during the entire period of studying in compliance with structural logic sequence of training.

When designing academic programs of combined (double) specialties the integrated disciplines of professional training are combined into modules (blocks) in each specialty.

In the context of our study it is important that professional knowledge is the basic "unit" of professional training. Its complexity is explained by the fact that professional knowledge is not homogeneous, it has the following three components: general professional knowledge which distinguishes one profession from another one, scientific subject (disciplinary) knowledge which has the scientific and technological nature, and purely professional, differentiated knowledge.

The scientific works review gives reasons to admit that there is no single approach to the definition of the phenomenon "interdisciplinary bonds". Scholars consider the interdisciplinary communication in the following ways: as independent didactic principle (V. Zverev); as a component of the principles of system and consistency (O. Bandura, K. Korolyova, P. Kulagin); as a condition of increasing the efficiency of the educational process (P. Novikova, F. Sokolova, N. Cherkes-Zadeh); as a way of forming ideology and various techniques of mental activity (V. Yantsen); as the organizational form of using certain material when studying certain phenomena (M. Baranov); as a way of the education functions implementation (E. Orlova).

According M. Kondakov [5, p. 338] the essence of integration is the interconnection that is enhanced by the interaction of all components of the whole in order to restore this unity. However, integration as a multifunctional concept in different situations may reflect different states of the interconnection and the process. Among the forms of interconnection the integration is the most selforganizing process. Thus, integration is an appropriate 
combination and coordination of actions of different parts of the entire system.

Interdisciplinary integration, in our opinion, is a system of teachers' and students' work that provides the unity of purposes, functions, content and structural elements of disciplines, promotes generalization, order and strength of professional knowledge and formation of a cohesive professional outlook and harmonious developed personality of a future specialist.

In modern studies there are different approaches to classifying the interdisciplinary communication, namely: content-methodological, operational-activity and organizational-methodical.

Interdisciplinary communication of contentmethodological type is classified by N. Tararaka according to the following criteria: the content of scientific knowledge (factual, conceptual, and theoretical); knowledge about the methods of scientific knowledge and ideological orientation (philosophical, historical, scientific, political, economic, ethical, aesthetic, and legal); unity of semantic elements of disciplines (objective, methodological, and theoretical).

Operational-activity interdisciplinary communication is characterized by the following criteria: practical methods of using theoretical knowledge (reproductive, constructive, creative); methods of teaching and learning activities (purely educational, developmental, and organizational-cognitive).

Organizational-methodical interdisciplinary communication is distinguished by:

- the methods of learning (reproductive, search, creative);

- the latitude of implementation (intercourse, incycle, inter-cycle);

- the time of implementation (following, accompanying, perspective);

- the way of the interconnection of objects (unilateral, bilateral, multilateral);

- the duration of realization (occasional, regular, systematic) [8, p. 132].

In current educational environment the integration (scientific, didactic, social) is considered as: an important means of optimizing the final result of professional training, the condition, method of increasing the efficiency and reducing the terms of mastering the basics of professional skills by future specialists (A. Belyaeva); as a process or state of reconstruction, recovery, replenishment, integration into the whole of previously isolated parts (I. Kozlovska); movement of the system to a large organic integrity (I. Yakovlev). V. Bezrukova understands educational integration as the creation of large teaching units based on the interconnection of the various components of the educational process.

According to I. Kozlovska it can be summarized that integration involves the variety of characteristics of elements which are integrated, and in the process of accumulation of quantitative traits and the emergence of new ones, the individual features of integrated elements are stored (the principle of unity, quality and quantity). The integration of knowledge clearly shows its feasibility. Regularity, necessity and eventuality in the context of using of integrated knowledge are fully expressed [4, p. 247].

In the current scientific works the basic philosophical concepts of integration of knowledge are fully described and analyzed - the concept of unity of the world and the universal connection of phenomena; the concept of integration of knowledge as the expression of human creativity [7, p. 105-114]. The integration of knowledge promotes its comprehensiveness - certain amount of integrated knowledge is considered to be didactically more comprehensive than the same amount of subject-specific knowledge. The efficiency of knowledge, namely the willingness to apply knowledge in similar and different situations, characterizes the precise knowledge of methods of implementation for the determination of situations. Integrative knowledge is much easier to use in new situations, as the integrative approach from the beginning prepares students to go beyond the ordinary situations [2, p. 113].

According to I. Smirnova, integrative approach assumes that the ability to use comprehensive knowledge, its synthesis, transfer of ideas and methods from one science to another one is the basis of creative approach to scientific, engineering, human artistic activity in modern scientific and technological progress [6, p. 104].

Proving the efficiency of actualization of interdisciplinary integration of professional disciplines in the process of training future specialists of socionomic field we should observe the practical aspect of the integrated approach in details.

The development of the directions of interdisciplinary integration can be based on the opinion of I. Bekh that the implementation of integration as a didactic principle in disciplines involves the form of their unification and presents them as a unity. It is about the construction of integrated training courses on the basis of which an appropriate educational process should take place. He recommends two positions for preparing the integrated courses, namely to determine how to present a comprehensive view of the studied phenomena, its limits and levels in a methodically proper way; according to this target, how to adjust the form of scientific knowledge representation in integrated study courses, which would be didactically formalized in each discipline [1, p. 5-6].

We consider the following directions of interdisciplinary integration to be the fundamental principles in context of our study: 1) the combination of several disciplines in a single integrated course; 2) the strengthening of coordination between disciplines, providing professional training of future banking specialists by the adjustment of curriculum and programs. Organizational forms of interdisciplinary integration of professional disciplines involve interdisciplinary excursions, practical lessons, seminars, individual lessons, various types of 
internship, extracurricular activities, and interdisciplinary groups.

\section{Conclusions}

Based on the above mentioned it can be noted that it is unnecessary to make adjustments in the content of professional disciplines which are taught for future specialists in the socionomic field. Interdisciplinary integration can be achieved by optimizing the structure blocks of educational material, by coordinating them according to their purpose.

An elective course can be used as the relevant approach for implementing this pedagogical condition, i. e. the course of integrative professional disciplines as an

\section{REFERENCES}

1. Bekh, I. D. (2003). Vykhovannya osobystosti: $u 2$ knyhakh. Knyha 2: Osobystisno oriyentovanyy pidkhid: naukovo-praktychni zasady [Education of the individual: in 2 books. Book 2: Student-centered approach: theoretical and practical basis]. Kyiv: Lybid [in Ukrainian].

2. Dutka, H. Ya. (2009). Pryntsyp fundamentalizatsiyi ta yoho realizatsiya u matematychniy pidhotovtsi maybutnikh ekonomistiv [Fundamentalization principle and its realization in the mathematical training of future economists]. Doctor's thesis. Kyiv [in Ukrainian].

3. Ziaziun, I. A. (2008). Filosofiya pedahohichnoi dii [Philosophy of teacher's activity]. Monograph. Kyiv, Cherkasy: Chernivtsi National University Publishing House named after B. Khmelnitsky [in Ukrainian].

4. Kozlovska, I. M. (2001). Teoretychni ta metodychni osnovy intehratsiyi znan uchniv profesiynotekhnichnoyi shkoly [Theoretical and methodological basis of integration of vocational school students' knowledge]. Doctor's thesis. Kyiv [in Ukrainian].

5. Kondakov, N. Y. (1975). Logicheskiy slovarspravochnik [Logical dictionary-directory]. Moscow: Nauka [in Russian].

\section{ЛІТЕРАТУРА}

1. Бех І. Д. Виховання особистості : у 2-х кн. / Іван Дмитрович Бех. - К. : Либідь, 2003. - Книга 2 : Особистісно орієнтований підхід: науково-практичні засади. -344 с

2. Дутка Г. Я. Принцип фундаменталізації та його реалізація у математичній підготовці майбутніх економістів : дис. ... доктора пед. наук : 13.00.04 / Ганна Яківна Дутка. - К., 2009. - 440 с.

3. Зязюн І. А. Філософія педагогічної дії : монографія / І. А. Зязюн. - К. ; Черкаси : Видавництво ЧНУ імені Б. Хмельницького, 2008. - 608 с.

4. Козловська І. М. Теоретичні та методичні основи інтеграції знань учнів професійно-технічної educational one, which is studied for deepening interdisciplinary (integrative) knowledge, forming interdisciplinary (productive) abilities of a certain profession, which is based on different types, forms, methods, and objects of inter-scientific integration.

Thus, interdisciplinary communication is a significant component of the concept of interdisciplinary integration, based on the unity of knowledge in all subjects into the entire system of methodically substantiated integral use. This didactic principle makes it possible to cover all aspects of the issue studied, as well as to provide the consistency in education and optimize the process of professional training of specialists in socionomic sphere.

6. Smirnova, V. O. (2006). Vprovadzhennya intehrovanoho pidkhodu do strukturuvannya pravovykh znan pedahoha profesiynoi shkoly [Implementation of the integrated approach to structuring the legal knowledge of teacher of vocational school]. Kyiv: TOV «Chayka Vsesvit» [in Ukrainian].

7. Sobko, Ya. M. (1999). Intehrovani kursy u profesiyno-tekhnichniy osviti: problemy oznachennya ta klasyfikatsiyi [Integrated courses in vocational education: problems of definition and classification]. Nauka $i$ suchasnist - Science and Modernity (pp. 105-114). M. V. Moklytsi (Ed.). Kyiv: NPU. [in Ukrainian].

8. Tararaka, N. H. (2008). Mizhpredmetni zvyazky vokalno-khorovykh dystsyplin u fakhovii pidhotovtsi maybutnoho vchytelya muzyky [Interdisciplinary communication of vocal and choral disciplines in professional training of future music teacher]. Candidate's thesis. Kharkiv [in Ukrainian].

школи : дис. ... доктора пед. наук : 13.00.04 / Ірина Михайлівна Козловська. - К., 2001. - 464 с.

5. Кондаков Н. И. Логический словарьсправочник / Н. И. Кондаков. - 2-е изд. - М. : Наука, 1975. $-720 \mathrm{c}$.

6. Смірнова В. О. Впровадження інтегрованого підходу до структурування правових знань педагога професійної школи : метод. рекомендації / В. О. Смірнова. - К. : ТОВ «Чайка - Всесвіт», 2006. $172 \mathrm{c}$.

7. Собко Я. М. Інтегровані курси у професійнотехнічній освіті: проблеми означення та класифікації / Я. М. Собко // Наука і сучасність : зб. наук. праць / 
редактор Моклиці М. В. - К. : НПУ, 1999. - Ч. 1. - С. 105-114.

8. Тарарака Н. Г. Міжпредметні зв'язки вокально-хорових дисциплін у фаховій підготовці майбут- нього вчителя музики : дис. ... кандидата пед. наук : 13.00.04 / Наталя Григорівна Тарарака . - Харків, 2008. -233 c.

Наталя Борисівна Беньковська, кандидат педагогічних наук, дочент кафедри іноземних мов, Одеський торговельно-економічний інститут Київського національного торговельно-економічного університету, вул. Інглезі, 6, м. Одеса, Украӥна

\section{МІЖДИСЦИПЛІНАРНА ІНТЕГРАЦІЯ ФАХОВИХ ДИСЦИПЛІН У ПРОЦЕСІ ПІДГОТОВКИ МАЙБУТНІХ ФАХІВЦІВ СОЦІОНОМІЧНОГО ПРОФІЛЮ}

У статті зазначається, що зміст фахової підготовки реалізується через інтегровані навчальні курси, що забезпечує системність у вивченні навчальних дисциплін, сприяє уникненню дублювання навчального матеріалу, зміцненню міжпредметних зв'язків та покращенню організації навчального процесу і запровадженню новітніх технологій навчання. 3'ясовано, що базовою «одиницею» фахової підготовки є професійні знання. Складність їх визначається тим, що вони не є однорідними, а містять три основних компоненти: загальнопрофесійні знання, які відрізняють одну професію від іншої, науково-предметні (дисциплінарні) знання, що мають науковотехнологічну природу, і суто фахові, диференційовані знання. Обгрунтовано, що міждисциплінарна інтеграція фахових дисциплін є системою роботи викладачів і студентів у процесі навчання, що передбачає єдність цілей, функцій, змістових і структурних елементів навчальних дисциплін, сприяє узагальненню, систематизації і міцності професійних знань і формуванню цілісного професійного світогляду й гармонійно розвиненої особистості майбутнього фахівця соціономічного профілю. Принциповими положеннями зазначено такі напрями міждисциплінарної інтеграції: 1) поєднання декількох дисциплін у єдиний інтегрований курс; 2) посилення координації між дисциплінами, що забезпечують фахову підготовку майбутнього фахівця соціономічної сфери шляхом узгодження навчальних планів і програм. До організаційних форм міждисциплінарної інтеграції фахових дисциплін віднесено міжпредметні екскурсії, практичні, семінарські та індивідуальні заняття, різноманітні види виробничої практики, факультативи, міжпредметні гуртки. Необов'язково вносити корективи у зміст фахових дисциплін, які викладаються майбутнім фахівцям соціономічної сфери, досягти міждисциплінарної інтеграції можна шляхом оптимізації структурних блоків навчального матеріалу, шляхом координації їх відповідно до поставленої мети.

Ключові слова: міждисциплінарна інтеграція, інтегровані навчальні дисципліни, міжпредметні зв’язки, професійні знання.

Reviewed by Doctor of Pedagogy, prof. H. Yavorska 